\title{
РЕТРОСПЕКТИВНИЙ АНАЛІЗ УСПІШНОСТІ ДЕНТАЛЬНИХ ІМПЛАНТАТІВ, ВСТАНОВЛЕНИХ У ДІЛЯНЦІ АУГМЕНТАЦІЇ КІСТКОВИМИ БЛОКАМИ АУТОГЕННОГО ТА АЛОГЕННОГО ПОХОДЖЕННЯ
}

\author{
○В. В. Русин, М. Ю. Гончарук-Хомин, А. Т. Кенюк \\ ДВНЗ «Ужгородський національний університет»
}

РЕЗЮМЕ. Динаміка та особливості ремоделювання різних за походженням кісткових блоків можуть безпосередньо впливати на результати успішності та виживання встановлених у них дентальних імплантатів, тому дослідження останніх показників $€$ важливим аспектом у плануванні та прогнозуванні наслідків ятрогенних втручань.

Мета дослідження - аналіз параметрів успішності встановлених дентальних імплантатів у ділянках аугментації кісткової тканини щелеп, що проводилася з використанням кісткових блоків аутогенного та алогенного походження, за даними попередньо проведених досліджень.

Матеріал і методи. Проведення дослідження відбувалося згідно з рекомендаціями щодо проведення системних оглядів та мета-аналізів клінічних досліджень, що передбачають оцінку результатів ятрогенних втручань, та висвітлені у Preferred Reporting Items for Systematic Reviews and Meta-Analyses (http://www.prisma-statement.org). 3 метою відбору публікацій, що потенційно можуть стосуватися до цілі та фокусного питання дослідження, був проведений електронний пошук у електронних базах даних MEDLINE®/PubMed®, Cochrane CENTRAL та Ovid MEDLINE. Пошук у електронних базах даних здійснювався згідно дескрипторів Medical Subject Headings (MeSH).

Результати. Враховуючи дані, отримані в ході аналізу публікацій, та основну мету проведеного дослідження, отримані результати можна згрупувати за наступними категоріями: успішність імплантатів, встановлених в аутологічні кісткові блоки, складала 93,0-98,5 \% (згідно з даними моніторингу - 368 імплантатів), 99,2 \% (згідно з даними моніторингу - 525 імплантатів), 94,11 \% (згідно з даними моніторингу - 45 імплантатів), 95,2 \% (згідно з даними моніторингу 21 імплантат), 86,9-90 \% (згідно з даними моніторингу - 43 імплантати), 83,3-96,9 \% (згідно з даними моніторингу - 53 імплантати), 94,1% (згідно з даними моніторингу - 162 імплантати), 96,4 \% (згідно з даними моніторингу 54 імплантати); успішність імплантатів, встановлених в алогенні кісткові блоки, склала 96 \% (згідно з даними моніторингу - 287 імплантатів), 95,5 \% (згідно з даними моніторингу - 90 імплантатів), 98 \% (згідно з даними моніторингу 63 імплантати).

Висновок. У ході аналізу публікацій виявлено, що показники успішності імплантатів залежать не тільки від обраного матеріалу для аугментації (його походження), а й від низки інших параметрів, таких як ділянка аугментації, період навантаження, період встановлення інтраосальних титанових опор відносно часу проведення реконструкції резидуального гребеня, топографії ділянки хірургічного втручання, часу спостереження, критеріїв, що були відібрані для оцінки показників успішності. Зокрема, при подовженні терміну спостереження показник успішності імплантації зменшувався, хоча даний параметр загалом не залежав від численності первинної вибірки встановлених імплантатів, за якими в подальшому проводився моніторинг.

КлючовІ СлОВА: імплантати; успішність; кісткова аугментація.

Вступ. Потреба порівняння результатів дентальної імплантації, проведеної в ділянках недостатньої кісткової пропозиції після попередньої процедури відновлення об'ємних параметрів резидуального гребеня, використовуючи для цього різні методики втручання та кісткові замінники у формі блоків, аргументована різними показниками успішності та прогнозованості таких ятрогенних маніпуляцій в залежності від походження кісткового аугментату $[5,6]$. Матеріали аутогенного та алогенного походження часто використовують у суміші при реалізації реконструкції альвеолярного гребеня, враховуючи остеокондутивні та остеоіндуктивні властивості першого виду трансплантата та можливість більш тривалої ретенції об'єму завдяки другому виду кісткового замінника $[9,10]$. Динаміка та особливості ремоделювання різних за походженням кісткових блоків можуть безпосередньо впливати на результати успішності та виживання встановлених у них дентальних імплантатів, тому дослідження цих показників $є$ важливим аспектом у плануванні та прогнозуванні наслідків ятрогенних втручань [6, $11,12,13]$.

Мета дослідження - аналіз параметрів успішності дентальних імплантатів, встановлених у ділянках аугментації кісткової тканини щелеп, яку проводили з використанням кісткових блоків аутогенного та алогенного походження, за даними попередньо проведених досліджень.

Матеріал і методи дослідження. Дослідження відбувалося згідно з рекомендаціями щодо проведення системних оглядів та мета-аналізів клінічних досліджень, що передбачають оцінку результатів ятрогенних втручань, та висвітлені у Ргеferred Reporting Items for Systematic Reviews and Meta-Analyses (http://www.prisma-statement.org). 3 метою відбору публікацій, які потенційно можуть 
Огляди літератури, оригінальні дослідження, погляд на проблему, ювілеї

мати відношення до цілі та фокусного питання дослідження, був проведений електронний пошук у електронних базах даних MEDLINE®/PubMed®, Cochrane CENTRAL та Ovid MEDLINE. Цей пошук здійснювали за дескрипторами Medical Subject Headings (MeSH), що є своєрідними заголовками [(( (८(((Dental Implants OR Dental Implants, Dental Implantation OR Dental Implantation, Endosseous [MeSH Major Topic])) AND (Alveolar ridge augmentation OR Alveolar bone grafting OR Bone Substitutes OR Bone Block [MeSH Major Topic])) AND randomized controlled trial[Publication Type]) AND Success Rate) ("2012"[Date - Publication] : "2017"[Date - Publication])]. При цьому були встановлені такі обмеження для аналізу досліджень, як англійська мова публікацій, рандомізований контрольований характер досліджень, а також попередні огляди, проведені з метою оцінки якості імплантації після проведення процедур реконструкції перспективних ділянок імплантації в умовах дефіциту кісткової пропозиції. Дослідження могли проводитися як на тваринних моделях, так і за участі пацієнтів, а глибина аналітичного зрізу становила 5 років (від 2012 до 2017 року). Згідно з критеріями проведення системних оглядів PICOS були обрані наступні: P (Роpulation): до складу проаналізованих контрольних досліджень були включені групи осіб віком від 18 до 65 років, у яких проводили аугментацію кісткової тканини щелеп із використанням кісткових блоків аутогенного, алогенного, ксеногенного та алопластичного походження, з подальшим проведенням у ділянці аугментації процедури дентальної імплантації; I (Interventions): аугментація кісткової тканини щелеп із використанням кісткових блоків різного походження з подальшим проведенням процедури дентальної імплантації; C (Comparison): рівнів успішності дентальних імплантатів, встановлених у ділянці аугментації аутогенними кістковими блоками та блоками кісткових замінників іншого походження; О (Outcomes): первинні наслідки - рівень успішності та виживання дентальних імплантатів, встановлених в ділянці аугментації кістковими блоками різного походження; вторинні наслідки - успішність процедури дентальної імплантації через призму сукупної оцінки результатів, як дентальної імплантації, так і кісткової аугментації; S (Study design): рандомізовані контрольовані дослідження, а також попередні огляди проведені з метою оцінки якості імплантації після проведення процедур реконструкції перспективних ділянок імплантації в умовах дефіциту кісткової пропозиції.

Результати й обговорення. В ході дослідження було проаналізовано 6 публікацій, які відповідали критеріям включення: Kang Y. H. et al. (2015) [8], Sakkas A. et al. (2017) [14], Ersani S. et al.
(2015), Aloy-Prosper A. et al. (2016) [2], Carini F. et al. (2014) [3, 4], Aloja E. D. (2013) [1]. У цих дослідженнях були представлені наступні періоди спостереження за пацієнтами: 36 місяців (Kang Y.-H. et al. (2015), Sakkas A. et al. (2017), Aloy-Prosper A. et al. (2016)), 26 місяців (Сагini F. et al. (2014)), 18 місяців (Aloja E. D. (2013)), 12 місяців (Ersani S. et al. (2015)). У дослідженні Kang Y.-H. et al. (2015) було проаналізовано 368 імплантатів (36 пацієнтів); Sakkas A. et al. (2017) - 525 імплантатів (259 пацієнтів), Ersani S. et al. (2015) - 45 імплантатів (32 пацієнти), Aloy-Prosper A. et al. (2016) - 53 імплантати (34 пацієнти), Carini F. et al. (2014) - 287 імплантатів (69 пацієнтів), Aloja E. D. (2013) - 90 імплантатів (28 пацієнтів).

У дослідженні Kang Y.-H. et al. (2015) було встановлено 368 імплантатів у 36 пацієнтів: 193 у кістковий аугментат, сформований з ділянки клубової кістки, та 175 - у трансплантати, зібрані внутрішньоротово, при цьому 225 імплантатів встановили на верхню щелепу, а 143 - на нижню [8]. Згідно з даними, отриманими в дослідженні, рівень успішності імплантатів через 3 роки коливався в межах 93,0-98,5 \%. При цьому в групі, у якій в якості трансплантата були використані блоки із ділянки клубового гребеня для проведення інлей-графтингу, рівень успішності трансплантатів становив 94,8 \%, а в групі з тим же типом проведення аугментації, але з використанням кісткових блоків, зібраних з ділянки ротової порожнини, 93,0 \%. При проведенні ж аугментації за типом онлей-графтингу рівень успішності імплантатів у другій групі дослідження був, навпаки, вищим 98,5 \%, ніж у першій групі. При цьому статистичних відмінностей щодо успішності імплантатів у двох групах порівняння не спостерігалося. Статистично значимі відмінності були виявлені за показниками приросту параметра висоти кісткової тканини, оскільки у першій групі такий складав лише 51,9 \% у момент часу Т5 (визначений дизайном дослідження у 3 роки), тоді як у другій групі цей показник складав 76,0%. Слід зазначити, що останні показники були зареєстрованими в умовах проведення аугментації за типом інлей-графтингу [8]. В той же час при проведенні онлей-графтингу була відмічена аналогічна тенденція до кращих резидуальних параметрів висоти аугментованого гребеня в периімплантатній ділянці, у розрізі якої показники співвідношення висоти залишкового гребеня до висоти в момент часу Т5 у другій групі становили 75,6 \%, а у першій групі - 53,1 \%. Різниця отриманих результатів аналізу, знову ж таки, була статистично достовірною. Автори дослідження зазначили, що хоча обидва види аутогенних кісткових блоків (зібраних з ділянки клубової кістки та внутрішньоротово) й демонструють аналогічні та статистично невідмінні результати 
Огляди літератури, оригінальні дослідження, погляд на проблему, ювілеї

успішності імплантатів, встановлених у ділянці реконструкції щелепи, проте використання кісткового блоку, сформованого не з внутрішньоротового кісткового депозиту, характеризується прогресуючою втратою кісткової тканини, найдинамічніші параметри редукції котрої спостерігаються у перші 6 місяців після аугментації. У даному дослідженні нечітко розмежовані поняття успішності та виживання імплантатів. Попередньо проведені дослідження виокремлюють поняття виживання імплантатів як відношення тієї кількості інтраосальних опор, що була встановлена, до тієї, що залишилась у порожнині рота на момент проведення оцінки. Показник успішності ж імплантатів визначається за відповідністю певним клінічним та рентгенологічним критеріям (стабільності, кровоточивості на зондування, втраті рівня периімплантатної кісткової тканини тощо). У ході опису методології дослідження Kang Y. H. et al. (2015) вказують, що були проаналізовані отримані показники стабільності імплантатів у формі значень ISQ, дані рентгенологічного аналізу змін висоти та щільності кісткового гребеня, однак не описують шкалу, за якою відбувалась оцінка саме успішності імплантатів [8].

Дослідження Sakkas A. et al. (2017) тривало впродовж 2009-2011 років, сумарно в ході дослідження 279 пацієнтам було проведено 456 процедур аугментації з використанням аутологічних кісткових блоків. Усі пацієнти були повторно оглянуті через 3 роки після проведення процедури імплантації, тобто показник втрати об'єктів дослідження дорівнював 0 [14]. Критерії, які використовували для оцінки успішності імплантації, були запропоновані Buser et al. та включали наступне: наявність імплантата на місці, відсутність перманентних порушень за типом болю чи дизестезії, відсутність периімплантатної інфекції, відсутність рухомості імплантата, відсутність персистуючих периапікальних просвітлень за результатами рентгенологічного контролю. Процедура імплантації в даному дослідженні проводилася через 3-5 місяців після процедури аугментації аутологічним кістковим блоком. Контроль пацієнтів здійснювали шляхом рентгенологічної та клінічної діагностики кожні 6 місяців до моменту досягнення дворічного періоду після фіксації протетичних конструкцій. 3456 процедур аугментації 436 були успішними, при цьому було втрачено 7 із 104 блоків, зібраних з ділянки нижньої щелепи, 2 з 113 аугментатів з виличної ділянки, 1 з 11 аугментатів з ділянки симфізу. Аугментація у всіх випадках здійснювалась за типом «bone block onlay». Рівень успішності встановлених імплантатів становив 99,2 \%. Середній період встановлення імплантатів після аугментації становив 4,53 місяця.
В ході дослідження було заплановано встановити 546 імплантатів, однак після аугментації виявилось, що придатних для імплантації умов вдалось домогтися у 259 пацієнтів (525 імплантатів у 436 аугментованих ділянках). 3 усіх встановлених інтраосальних опор 300 були встановлені на верхній щелепі і 25 - на нижній. Ранню невдачу імплантації спостерігали в ділянці двох імплантатів, аналогічна кількість ускладнень була відмічена і на пізніх періодах спостереження. Рівень виживання імплантатів при цьому становив 99,6 \% на момент закінчення дворічного спостереження після фіксації протетичних супраконструкцій [14]. За даними дослідження вдалося встановити, що аутологічний трансплантат у формі блока забезпечує високі показники успішності імплантатів, тому його можна й далі вважати так званим золотим стандартом у передпротетичній дентоальвеолярній підготовці пацієнта до імплантації. Крім того, в даному дослідженні вдалося довести, що високий показник успішності імплантатів характерний для специфічних умов клінічної ситуації: реконструкції сильно атрофованих ділянок щелеп з використанням кортикально-губчастого трансплантата аутогенного походження. В даному дослідженні не проводилося порівняння показника успішності імплантатів, встановлених в аутологічні та інші за походженням типи блоків, однак значна вибірка пацієнтів та деталізований аналіз даних дозволяють використовувати показники успішності для порівняння із даними інших досліджень.

У дослідженні Ersani S. et al. (2015) взяли участь 32 чоловіки, в яких був дефіцит кісткової пропозиції у фронтальній ділянці верхньої щелепи. Виходячи 3 клінічних умов пацієнтам групи вибірки була проведена аугментація проблемної ділянки із використанням кісткових блоків, сформованих 3 ділянки симфізу чи гілки нижньої щелепи за принципом «autogenous bone block transfer». Загоєння блоків відбувалося впродовж 4 місяців, після чого було розпочате встановлення дентальних імплантатів. Сумарно було встановлено 45 інтраосальних опор: 28 - у ділянку аугментації блоком, сформованим із симфізу щелепи, 17 - у блок, сформований із ділянки гілки щелепи. Успішність імплантатів оцінювали за критеріями Albrektsson. Показники виживання та успішності імплантації у кінці дослідження становили 96,42 \% та 94,11 \% відповідно. Аналіз результатів в даному дослідженні проводили через один рік після встановлення імплантатів, а тому, на думку авторів, для отримання більш достовірних даних необхідно провести подальші дослідження із подовженням терміну спостереження.

Aloy-Prosper A. et al. (2016) порівняли отримані результати імплантації при імплементації безпосереднього та відстроченого протоколу вста- 
Огляди літератури, оригінальні дослідження, погляд на проблему, ювілеї

новлення інтраосальних опор у ділянці аугментації аутогенними кістовими блоками [2]. У ході дослідження успішність оцінювали за критеріями Buser. У дослідженні взяли участь 34 пацієнти, яким було встановлено усього 53 імплантати. 353 конструкцій 23 були встановлені за відстроченим протоколом, а 30 - безпосередньо з процедурою аугментації. Через три роки функціонування імплантатів у якості опор ортопедичних конструкцій кумулятивний показник успішності становив 83,3 \% для групи з безпосереднім встановленням імплантатів, та 96,9 \% - для групи, у якій був реалізований відстрочений протокол імплантації. При цьому відрізнявся і показник середньої резорбції маргінального рівня кістки, який при відстроченій процедурі становив $(0,29 \pm 0,35)$ мм, а при безпосередній - $(1,15 \pm 1,67)$ мм. Результати даного дослідження вказують на те, що показники успішності імплантатів відрізняються не тільки при використанні різних за походженням типів блоків, а й від протоколу втручання. Отримані результати свідчать, що відстрочений алгоритм імплантації забезпечує ефективніші результати лікування за показниками втрати кісткової тканини та успішності наявних імплантатів.

Дослідження, проведене Carini et al. (2014), проходило за участі 69 пацієнтів, аугментація у котрих проводилася із використанням свіжозамороженої алогенної кістки у формі блоків лише в ділянці верхньої щелепи [3, 4]. Кістковий трансплантат був отриманий з Veneto Tissue Bank (Iталія). Встановлення імплантатів у середньому відбувалося через 6 місяців після підсадки алографта. Всі імплантати, встановлені в ході дослідження, були встановлені лише в ділянках попередньої аугментації. Сумарно було зазеньковано 287 інтраосальних опор, 169 з яких у пацієнтів з частковою адентією, а 118 - у пацієнтів з повною адентією. Показник успішності імплантатів у даному випадку визначався за наступними критеріями Albreksstonn та Zarb: 1) відсутність ознак периімплантатної інфекції; 2) відсутність рухомості імплантата; 3) відсутність персистуючої резорбції оточуючої кісткової тканини більше ніж 1,5 мм в перший рік навантаження титанових опор і з динамікою не більше 0,2 мм за рік в наступний період. Середній період спостереження за імплантатами становив 26 місяців. У шестимісячний постопераційний період було втрачено 5 імплантатів, а показник успішності складав 98,3 \%. Базуючись на критеріях успішності, описаних вище, кумулятивний показник даного параметра становив $96 \%$ у перший рік після імплантації, але зменшився до 40 \% через чотири роки. Аналогічно зросли показники втрати кісткової тканини, оскільки динаміка резорбції у перший рік складала 1,68 мм, а після чо- тирьох років - 1,85 мм [3, 4]. У дослідженні також використовували алгоритм Каплан-Мейера для дослідження впливу типу адентії та типу протетичної реставрації на показник успішності імплантації, що дозволило встановити, що показники успішності $€$ відносно кращими при використанні повних знімних протезів у клінічних умовах повної адентії. Впливу показників діаметра, довжини чи місця імплантації на параметр успішності інтраосальних конструкцій встановити не вдалося.

Дослідження Aloja E. D. (2013) проводилося на базі Instituto Stomatologico Tirreno (Італія), в його ході брали участь 28 пацієнтів, яким проводилася процедура синус-ліфту. В якості трансплантата у всіх випадках використовували алотрансплантати у формі блоків, забрані з Bone Bank (Італія) [1]. Загалом було використано 42 кісткових блоки, в які було встановлено 90 імплантатів через 6 місяців після проведення процедури аугментації. Рівень виживання імплантатів складав 95,5 \% на момент закінчення 18-місячного періоду спостереження. Дослідники не вказують критеріїв, за якими проводилась оцінка успішності імплантатів, але зазначають, що всі із тих, що залишилися, можуть бути класифіковані як успішні. Крім того, втрату імплантатів автори пов'язують не з впливом типу кісткового блоку, який використовували, а із наявністю у пацієнтів шкідливої звички куріння та гіпертензії.

Враховуючи дані, отримані в ході аналізу публікації, та основну мету проведеного дослідження, отримані результати можна згрупувати за наступними категоріями: успішність імплантатів, встановлених в аутологічні кісткові блоки, - 93,098,5 \% (згідно з даними моніторингу 368 імплантатів), 99,2 \% (згідно з даними моніторингу 525 імплантатів), 94,11 \% (згідно з даними моніторингу 45 імплантатів), 83,3-96,9% (згідно з даними моніторингу 53 імплантатів); успішність імплантатів, встановлених в алогенні кісткові блоки, - 96 \% (згідно 3 даними моніторингу 287 імплантатів), 95,5 \% (згідно з даними моніторингу 90 імплантатів).

При порівнянні даних отриманого системного аналізу із даними попередньо проведених системних аналізів можна відмітити їх суміжність та аналогічність. За даними Motamedian S.R. et al. (2016), який загалом проаналізував 470 досліджень, з яких, згідно з критеріями включення, було відібрано 36, що були присвячені вивченню успішності імплантатів, встановлених в аутологічні кісткові блоки, а 23 - в алогенні кісткові блоки, успішність перших коливалася в межах 72,8$100 \%$, а других - 93,7-100 \% [11]; за даними системного огляду Clementini M. (2012), який загалом проаналізував 323 дослідження, з яких, згідно з критеріями включення, було відібрано 8 присвячених оцінці успішності імплантатів, вста- 
Огляди літератури, оригінальні дослідження, погляд на проблему, ювілеї

новлених в ділянці аугментації аутологічним матеріалом, успішність таких внутрішньокісткових титанових опор коливалась в діапазоні 72,8-97\%, при цьому успішність імплантатів вище 84 \% була зареєстрована лише у двох дослідженнях [6].

Висновок. Показники успішності імплантатів залежать не тільки від обраного матеріалу для аугментації (його походження), а й від низки інших параметрів, таких як ділянка аугментації, період навантаження, період встановлення інтраосальних титанових опор відносно часу проведення реконструкції резидуального гребеня, топографії ділянки хірургічного втручання, часу спостереження, критеріїв, що були відібрані для оцінки показників успішності. При подовженні терміну спостереження було відмічено зменшення показника успішності імплантації, хоча цей параметр загалом не залежав від численності первинної вибірки встановлених імплантатів, за якими в подальшому проводився моніторинг. Отримані результати ретроспективного аналізу можна представити наступним чином: діапазон успішності імплантатів, встановлених в аутологічні кісткові блоки, склав - 83,3-99,2 \%, в алогенні кісткові блоки - 95,5-96\%.

Перспективи подальших досліджень. Оскільки динаміка та особливості ремоделювання різних за походженням кісткових блоків можуть безпосередньо впливати на результати успішності та виживання встановлених у них дентальних імплантатів, подальші дослідження будуть спрямовані на об'єктивізацію оцінки змін кісткових замінників у процесі ремоделювання, критерії якої згодом можуть використовуватися на етапах планування та прогнозування результатів ятрогенних втручань.

\section{ЛІТЕРАТУРА}

1. The use of bone block allografts in sinus augmentation, followed by delayed implant placement: A case series / E. D. Aloja, M. Ricci, G. Caso [et al.] // Contemporary Clinical Dentistry. - 2013. - No. 4 (1). - P. 13.

2. Aloy-Prósper A. The outcome of intraoral onlay block bone grafts on alveolar ridge augmentations: a systematic review / A. Aloy-Prósper, D. Peñarrocha-Oltra, M. Peñarrocha-Diago // Med. Oral Patol. Oral Cir. Bucal. 2015. - No. 20 (2). - P. e251-258.

3. Bone augmentation with TiMesh. autologous bone versus autologous bone and bone substitutes. A systematic review / F. Carini, S. Longoni, E. Amosso [et al.] // Annali di Stomatologia. - 2014. - No. 5 (2). - P. 27.

4. Immediate loading of implants in the aesthetic zone: comparison between two placement timings / F. Carini, S. Longoni, V. Pisapia [et al.] // Annali di Stomatologia. 2014. - No. 5 (2). - P. 15.

5. Success rate of dental implants inserted in autologous bone graft regenerated areas: a systematic review / M. Clementini, A. Morlupi, C. Agrestini, A. Barlattani // Clinical Oral Implants Research. - 2009. - No. 20 (9). - P. 987.

6 . Success rate of dental implants inserted in autologous bone graft regenerated areas: a systematic review / M. Clementini, A. Morlupi, C. Agrestini, L. Ottira // Oral Implantol. (Rome). - 2011. - No. 4 (3-4). - P. 3-10.

7. Short implants versus longer implants in vertically augmented posterior mandibles: a randomised controlled trial with 5-year after loading follow-up / P. Felice, G. Cannizzaro, C. Barausse [et al.] // Eur. J. Oral Implantol. 2014. - No. 7 (4). - P. 359-369.
8. Stability of simultaneously placed dental implants with autologous bone grafts harvested from the iliac crest or intraoral jaw bone / Y. H. Kang, H. M. Kim, J. H. Byun [et al.] // BMC Oral Health. - 2015. - No. 15 (1). - P. 172.

9. Misch C. E. Bone-grafting materials in implant dentistry / C. E. Misch, F. Dietsh // Implant Dentistry. - 1993. No. 2 (3). - P. 158-166.

10. Implant success, survival, and failure: the International Congress of Oral Implantologists (ICOI) pisa consensus conference / C. E. Misch, M. L. Perel, H. L. Wang [et al.] // Implant Dentistry. - 2013. - No. 17(1). - P. 5-15.

11. Motamedian S. R. Success rate of implants placed in autogenous bone blocks versus allogenic bone blocks: a systematic literature review / S. R. Motamedian, M. Khojaste, A. Khojasteh // Annals of Maxillofacial Surgery. 2016. - No. 6 (1). - P. 78.

12. Success criteria in implant dentistry: a systematic review / P. Papaspyridakos, C. J. Chen, M. Singh [et al.] // Journal of Dental Research. - 2012. - No. 91 (3). P. 242-248.

13. A systematic review of the success of sinus floor elevation and survival of implants inserted in combination with sinus floor elevation / B. E. Pjetursson, W. C. Tan, M. Zwahlen, N. P. Lang // Journal of Clinical Periodontology. - 2008. - No. 35 (s8). - P. 216-240.

14. Autogenous bone grafts in oral implantology - is it still a "gold standard"? A consecutive review of 279 patients with 456 clinical procedures / A. Sakkas, F. Wilde, M. Heufelder [et al.] // International Journal of Implant Dentistry. - 2017. - No. 3 (1). - P. 23. 
Огляди літератури, оригінальні дослідження, погляд на проблему, ювілеї REFERENCES

1. Aloja, E.D., Ricci, M., Caso, G., Santi, E., Paolo, T., Antono, B., \& Covani, U. (2013). The use of bone block allografts in sinus augmentation, followed by delayed implant placement: A case series. Contemporary Clinical Dentistry, 4 (1), 13.

2. Aloy-Prósper, A., Peñarrocha-Oltra, D., \& Peñarrocha-Diago, M. (2015). The outcome of intraoral onlay block bone grafts on alveolar ridge augmentations: a systematic review. Med. Oral Patol. Oral Cir. Bucal., 20 (2), e251-258.

3. Carini, F., Longoni, S., Amosso, E., Paleari, J., Carini, S., \& Porcaro, G. (2014). Bone augmentation with TiMesh. autologous bone versus autologous bone and bone substitutes. A systematic review. Annali di Stomatologia, 5 (2), 27.

4. Carini, F., Longoni, S., Pisapia, V., Francesconi, M., Saggese, V., \& Porcaro, G. (2014). Immediate loading of implants in the aesthetic zone: comparison between two placement timings. Annali di Stomatologia, 5 (2 2), 15.

5. Clementini, M., Morlupi, A., Agrestini, C., \& Barlattani, A. (2009). Success rate of dental implants inserted in autologous bone graft regenerated areas: a systematic review. Clinical Oral Implants Research, 20 (9), 987.

6. Clementini, M., Morlupi, A., Agrestini, C., \& Ottria, L. (2011). Success rate of dental implants inserted in autologous bone graft regenerated areas: a systematic review. Oral Implantol. (Rome), 4 (3-4), 3-10.

7. Felice, P., Cannizzaro, G., Barausse, C., Pistilli, R., \& Esposito, M. (2014). Short implants versus longer implants in vertically augmented posterior mandibles: a randomised controlled trial with 5-year after loading follow-up. Eur. J. Oral Implantol., 7 (4), 359-369.
8. Kang, Y.H., Kim, H.M., Byun, J.H., Kim, U.K., Sung, I.Y., Cho, Y.C., \& Park, B.W. (2015). Stability of simultaneously placed dental implants with autologous bone grafts harvested from the iliac crest or intraoral jaw bone. BMC Oral Health, 15 (1), 172.

9. Misch, C.E., \& Dietsh, F. (1993). Bone-grafting materials in implant dentistry. Implant Dentistry, 2 (3), 158-166.

10. Misch, C.E., Perel, M.L., Wang, H.L., Sammartino, G., Galindo-Moreno, P., Trisi, P., ... \& Schwartz-Arad, D. (2008). Implant success, survival, and failure: the International Congress of Oral Implantologists (ICOI) pisa consensus conference. Implant Dentistry, 17 (1), 5-15.

11. Motamedian, S.R., Khojaste, M., \& Khojasteh, A. (2016). Success rate of implants placed in autogenous bone blocks versus allogenic bone blocks: a systematic literature review. Annals of maxillofacial surgery, 6 (1), 78.

12. Papaspyridakos, P., Chen, C.J., Singh, M., Weber, H.P., \& Gallucci, G.O. (2012). Success criteria in implant dentistry: a systematic review. Journal of Dental Research, 91 (3), 242-248.

13. Pjetursson, B.E., Tan, W.C., Zwahlen, M., \& Lang, N.P. (2008). A systematic review of the success of sinus floor elevation and survival of implants inserted in combination with sinus floor elevation. Journal of Clinical Periodontology, 35 (s8), 216-240.

14. Sakkas, A., Wilde, F., Heufelder, M., Winter, K., \& Schramm, A. (2017). Autogenous bone grafts in oral implantology - is it still a "gold standard"? A consecutive review of 279 patients with 456 clinical procedures. International Journal of Implant Dentistry, 3 (1), 23.

\title{
РЕТРОСПЕКТИВНЫЙ АНАЛИЗ УСПЕШНОСТИ ДЕНТАЛЬНЫХ ИМПЛАНТАТОВ, УСТАНОВЛЕННЫХ В ОБЛАСТИ АУГМЕНТАЦИИ КОСТНЫМИ БЛОКАМИ АУТОГЕННОГО И АЛЛОГЕННОГО ПРОИСХОЖДЕНИЯ
}

\author{
๑В. В. Русин, М. Ю. Гончарук-Хомин, А. Т. Кенюк \\ ГВУз «Ужгородский национальный университет»
}

РЕЗЮМЕ. Динамика и особенности ремоделирования разных по происхождению костных блоков могут непосредственно влиять на результаты успешности и выживания установленных в них дентальных имплантатов, поэтому исследование последних показателей является важным аспектом в планировании и прогнозировании последствий ятрогенных вмешательств.

Цель исследования - анализ параметров успешности установленных дентальных имплантатов в участках аугментации костной ткани челюстей, где она проводилась с использованием костных блоков аутогенного и аллогенного происхождения, по данным предварительно проведенных исследований.

Материал и методы. Исследование проводилось согласно рекомендациям по проведению системных обзоров и мета-анализов клинических исследований, предусматривающих оценку результатов ятрогенных вмешательств, и приведенных в Preferred Reporting Items for Systematic Reviews and Meta-Analyses (http://www.prismastatement.org). С целью отбора публикаций, которые могут иметь отношение к цели и фокусу исследования, был проведен электронный поиск в электронных базах данных MEDLINE® / PubMed®, Cochrane CENTRAL и Ovid MEDLINE. Поиск в электронных базах данных осуществлялся согласно дескрипторам Medical Subject Headings (MeSH).

Результаты. Учитывая данные, полученные в ходе анализа публикаций, и основную цель проведенного исследования, полученные результаты можно сгруппировать по следующим категориям: успешность имплантатов, установленных в аутологичные костные блоки, составляла 93,0-98,5 \% (по данным мониторинга - 368 имплантатов), 99,2% (по данным мониторинга - 525 имплантатов), 94,11\% (по данным мониторинга - 45 имплантатов), 95,2 \% (по данным мониторинга - 21 имплантат), 86,9-90 \% (по данным мониторинга - 43 имплантата), 83,396,9 \% (по данным мониторинга - 53 имплантата), 94,1 \% (по данным мониторинга - 162 имплантата) 96,4% (по 
Огляди літератури, оригінальні дослідження, погляд на проблему, ювілеї

данным мониторинга - 54 имплантата); успешность имплантатов, установленных в аллогенные костные блоки, составляла 96 \% (по данным мониторинга - 287 имплантатов), 95,5% (по данным мониторинга - 90 имплантатов), $98 \%$ (по данным мониторинга - 63 имплантата).

Вывод. В ходе анализа публикаций было отмечено, что показатели успешности имплантатов зависят не только от выбранного материала для аугментации (его происхождения), но и от ряда других параметров, таких как область аугментации, период нагрузки, период установления интраосальных титановых опор относительно времени проведения реконструкции резидуального гребня, топографии области хирургического вмешательства, времени наблюдения, критериев, которые были отобраны для оценки показателей успешности. В частности, при продлении срока наблюдения было отмечено уменьшение показателя успешности имплантации, хотя данный параметр вообще не зависел от численности первичной выборки установленных имплантатов, по которым в дальнейшем проводился мониторинг.

КЛЮЧЕВЫЕ СЛОВА: имплантаты; успешность; костная аугментация

\title{
RETROSPECTIVE ANALYSIS OF SUCCESS RATE OF DENTAL IMPLANTS INSTALLED IN THE AREA OF BONE AUGMENTATION WITH THE USE OF AUTOGENIC AND ALLOGENIC BLOCKS
}

\author{
@V. V. Rusyn, M. Y. Goncharuk-Khomyn, A. T. Keniuk \\ Uzhhorod National University
}

SUMMARY. The dynamics and features of remodeling bone blocks of different origin can directly influence the results of dental implants success and survival installed in the area of augmentation, therefore the study of the latter indicators is an important aspect in planning and predicting the effects of iatrogenic interventions.

The aim of the study - to analyze the parameters of the success among installed dental implants in the sites of jaw bone augmentation, which was carried out using bone blocks of autogenic and allogeneic origin, according to data from previous studies.

Material and Methods. The study was conducted in accordance to the recommendations for systematic reviews and meta-analyzes of clinical trials assessing the results of iatrogenic interventions and are covered in Preferred Reporting Items for Systematic Reviews and Meta-Analyzes (http://www.prisma-statement.org). In order to select publications that are potentially relevant to the purpose and focus of the study, an electronic search of such electronic databases as MEDLINE $®$ / PubMed $®$, Cochrane CENTRAL and Ovid MEDLINE was carried out. The search for electronic databases was performed according to the Medical Subject Headings (MeSH) descriptors.

Results. Taking into account the data obtained during the analysis of the publication and the main purpose of the study, the results can be grouped according to the following categories: the success of the implants installed in the autologous bone blocks was: 93.0-98.5\% (according to monitoring data of 368 implants), $99.2 \%$ (according to monitoring data of 525 implants), 94.11 \% (according to monitoring data of 45 implants), $95.2 \%$ (according to 21 implant monitoring data), 86.9-90\% (according to monitoring data of 43 implants), 83.3-96.9\% (according to monitoring data of 53 implants), $94.1 \%$ (according to monitoring data, 162 implants) 96.4 \% (according to monitoring data 54 implants); the success of implants installed in allogenic bone blocks: 96 \% (according to the monitoring data of 287 implants), $95.5 \%$ (according to monitoring data of 90 implants), 98 \% (according to monitoring data of 63 implants).

Conclusion. During the analysis of publications, it was noted that the success rates of implants depend not only on the selected material for augmentation (its origin), but also on a number of other parameters such as the region of augmentation, the load period, the period of the implant installation in relation to the time of the residual ridge reconstruction, the topography of the surgical area, the time of observation, the criteria that were selected to assess the success rate. In particular, when the observation period was lengthened, a decrease in the success rate of implantation was noted, although this parameter generally did not depend on the number of primary samples of installed implants, on which further monitoring was carried out.

KEY WORDS: implants; success; bone augmentation. 